\title{
Beş Büyük Kişilik Özelliği ve Öz Yeterliliğin Sosyal Medyada Yer Alan Sahte Haberlerin Kabulü ve Yayılması Üzerindeki Etkisi
}

\author{
Sinem Sargın ${ }^{1 *}$, Kumru Uyar², Esra Kahya Özyirmidokuz ${ }^{3}$ \\ $\mathbf{1}^{*}$ Nuh Naci Yazgan Üniversitesi, İktisadi İdari Bilimler Fakültesi, İşletme Bölümü, Kayseri, Türkiye, (ORCID: 0000-0002-7504-154X), ssargin@,nny.edu.tr \\ ${ }^{2}$ Erciyes Üniversitesi, İktisadi İdari Bilimler Fakültesi, İşletme Bölümü, Kayseri, Türkiye (ORCID: 0000-0002-2604-5317), kumruuyar@erciyes.edu.tr \\ ${ }^{3}$ Erciyes Üniversitesi, İktisadi İdari Bilimler Fakültesi, İşletme Bölümü, Kayseri, Türkiye (ORCID: 0000-0001-8255-1313), esrakahya@erciyes.edu.tr
}

(International Conference on Design, Research and Development (RDCONF) 2021 - 15-18 December 2021)

DOI: $10.31590 /$ ejosat.1040099)

ATIF/REFERENCE: Sargın, S., Uyar, K., \& Özyirmidokuz, E. K. (2021). Beş Büyük Kişilik Özelliği ve Öz Yeterliliğin Sosyal Medyada Yer Alan Sahte Haberlerin Kabulü ve Yayılması Üzerindeki Etkisi. Avrupa Bilim ve Teknoloji Dergisi, (32), 979-990.

$\ddot{\mathbf{O z}}$

Sosyal medyada yer alan haberlerin güvenilirliği oldukça düşüktür. Sahte haberler tüketiciler ve markalar üzerinde oldukça olumsuz etkiler bırakmaktadır. Bu doğrultuda, bu çalışmanın amacı tüketicilerin kişilik özelliklerinin ve öz yeterliliklerinin sosyal medyada yer alan sahte haberlerin kabulü ve bu haberleri kullanma niyeti üzerindeki etkisini incelemektir. Kolayda örnekleme yöntemiyle belirlenen 408 tüketici üzerinde çevrimiçi anket uygulaması yapılmışır. Veriler SPSS paket programı aracılığıyla analiz edilmiştir. Araştırmanın bulguları sonucunda, beş büyük kişilik özelliği boyutlarından dışa dönüklük ve duygusal denge (nevrotiklik) boyutlarının sahte haberlerin kabulü üzerinde etkili olduğu; fakat deneyime açıklık, uyumluluk ve sorumluluk boyutlarının etkili olmadığı; öz yeterliliğin sahte haberlerin kabulü üzerinde anlamlı bir etkisinin bulunmadı̆̆ı; sahte haberlerin kabulünün sahte haberleri kullanma niyeti üzerinde etkili olduğu tespit edilmiştir.

Anahtar Kelimeler: Beş Büyük Kişilik Özelliği, Öz Yeterlilik, Sahte Haberlerin Kabulü, Sahte Haberlerin Yayılması.

\section{The Effect of Big Five Personality Traits and Self-Efficacy on the Acceptance and Spread of Fake News in Social Media}

\begin{abstract}
The credibility of the news on social media is very low. Fake news has a very negative effect on consumers and brands. In this direction, the purpose of this study is to examine the effect of consumer personality traits and self-efficacy on the acceptance of fake news on social media and the intention to use these news. An online questionnaire was conducted on 408 consumers selected by convenience sampling method. The data were analyzed using the SPSS package program. According to findings, it was determined that extraversion and emotional balance (neuroticism), among the big five personality traits, were effective on the acceptance of fake news; however, the dimensions of openness to experience, agreeableness and conscientiousness were not. Self-efficacy does not have a significant effect on the acceptance of fake news; besides, the acceptance of fake news is effective on the intention to use fake news.
\end{abstract}

Keywords: Big Five Personality Traits, Self-Efficacy, Acceptance of Fake News, Spread of Fake News

*Sorumlu Yazar: ssargin@nny.edu.tr 


\section{Giriş}

Sosyal medyanın, bireysel hesaplardan yapılan anlık paylaşımlar sebebiyle, haberlerin bireylere aktarılmasında süre ve hız bakımından büyük kolaylık sağladığı bilinse dahi; güvenilir olma, gerçeklik düzeyi ve yanıltıcı olma konularında çoğu zaman tehlike yarattığ 1 da bir gerçektir. Bilen ile bilmeyenin, iyi veya kötünün, doğru ile yalanın arasındaki farkın belirsiz duruma geldiği sosyal medya platformlarında paylaşım çılgınlığına kapılan her birey; kaynağı belli olmayan haberlere düşünmeden inanmakta ve bunları sonuçlarını değerlendirmeden paylaşmaktadır. Bunun bir sonucu olarak da, sosyal medya kullanıcıları, bazen hiç farkında olmadan da olsa, bu paylaşım kirliliğine hizmet etmektedirler. Bu yanıltıcı haberler; markalar açısından da ciddi bir tehdit oluşturmakta ve markalar sahte haberlerden çeşitli şekillerde etkilenmektedirler. Sosyal medyada yer alan sahte haberler markalar ve firmalar açısından büyük önem taşımaktadır ve pazarlama uygulayıcılarının marka imajı ve marka değerini korumak adına, bu haberlerin üretilmesi ve yayılmasıyla mücadele etmeleri gerekmektedir. Bu nedenle sahte haberler, pazarlama dünyasında araştırılması ve çözüm bulunması gereken önemli sorunların başında yer almaktadır.

Sahte haberlerle ilgili daha önce yapılan çalışmalar incelendiğinde, sosyal medyada paylaşılan haberlerin yayılmasında kültür ve demografik özelliklerin etkisinin bulunduğu görülmektedir (Rampersad ve Althiyabi, 2020). Bu doğrultuda, sosyal medyada yer alan sahte haberlerin kabul edilmesi ve yayılmasında kullanıcıların kişilik özelliklerinin ve öz yeterlilik düzeylerinin de etkili olabileceği düşünülmektedir.

Beş Büyük (Big Five) Kişilik modeli, kişilik teorilerinden yola çıkan ve kişilik özelliklerinin sınıflandırıldığı bir modeldir ve deneyime açıklık, sorumluluk, dışa dönüklük, uyumluluk ve duygusal denge (nevrotiklik) olmak üzere 5 boyuttan meydana gelmektedir (Costa ve McCrae, 1995). Öz yeterlilik kavramı ise, bireyin karşılaştığı durumlarla başa çıkabilmek için yapılması gerekenleri planlama ve yürütme kabiliyetine olan inanç düzeyini ifade etmektedir.

Sahte haberler yazını incelendiğinde, kişilik özellikleriyle sahte haberler arasındaki ilişkiyi ele alan yalnızca bir çalışmaya rastlanmıştır (Buchanan ve Benson, 2019). Öz yeterliliğin sahte haberlerle ilişkisini inceleyen çalışmada ise (Chen ve Cheng, 2019), öz yeterliliğin sahte haberlerin tüketiciler tarafindan algılanma biçimi üzerindeki etkisi incelenmiştir. Fakat kişilik özellikleri ve öz yeterliliğin sahte haberlerin kabulü ve yayılması üzerindeki etkisini bir arada inceleyen herhangi bir çalışmaya rastlanmamıştır. $\mathrm{Bu}$ bağlamda, çalışmanın literatüre katkı sağlaması beklenmektedir.

$\mathrm{Bu}$ doğrultuda çalışmanın amacı, beş büyük kişilik özelliğinin ve öz yeterliliğin, sosyal medyada yer alan sahte haberlerin kabulü ve kullanımı (yayılması) üzerindeki etkisi incelemektir. Bu kapsamda, çalışmada öncelikle beş büyük kişilik özelliği ve öz yeterlilik unsurları ile sahte haberlerin kabulü ve yayılması üzerinde durulacaktır. Daha sonra araştırmanın yöntemi, verilerin analizi, araştırmanın bulguları, bulguların değerlendirilmesi ile sonuç bölümü yer alacaktır.

\section{Kavramsal Çerçeve}

\subsection{Beş Büyük Kişilik Özelliği}

Kişilik kavramının genel kabul görmüş bir tanımı bulunmamasına rağmen, genel anlamda bir insanı diğerlerinden e-ISSN: 2148-2683 farklılaştıran, ayırt edici niteliklerin tamamı olarak ifade edilmektedir. Başka bir ifadeyle kişilik, insanların eylemleri konusunda belirleyici olan nitelikler şeklinde de tanımlanabilir. Burger (2006) tarafından kişilik, bir bireyin öz iradesiyle gerçekleştirdiği istikrarlı davranış biçimleri ve süreçler olarak belirtilmektedir. Burada vurgulanmak istenen temel nokta, kişiliğin istikrarlı olmasıdır. Örneğin, dışadönük olan ve bu yönde davranışlar gerçekleştiren bir kişinin gelecekte de aynı şekilde davranmasını bekleriz.

McCrae ve Costa (1990) ise kişiliği; bireylerin farklı özellikleri neticesinde tutum ve davranışlarını şekillendiren bir yap1 olarak ifade etmektedirler. Kişiliğin genel kabul görmüş ortak bir tanımı olmamasına rağmen, kişilik alanında yapılan araştırmaların çoğunlukla üzerinde durduğu kişilik modeli beş faktör kişilik modelidir. Beş faktör kişilik modeli (beş büyük kişilik özelliği); dişadönüklük, nevrotiklik (duygusal denge), uyumluluk, dürüstlük ve deneyime açıklık olmak üzere beş boyuttan oluşan bir modeldir (Goldberg, 1990; Burger, 2006; McCrae ve Costa, 2008).

Deneyime açıklık (Openness), yaratıcı ve hayalperest kişileri dünyaya yüzeysel bakan alışılmış bireylerden ayırt eden bir kişilik özelliğidir. Başka bir ifadeyle deneyime açıklık, kendine özgü olmayı, farklı tecrübeler edinme konusundaki eğilim derecesini ifade eder (Costa ve McCrae, 1992: 653-665). Sorumluluk (Conscientousness), bireylerin içü̈dülerini nasıl kontrol altına aldıklarını ifade etmektedir. Bu kişilik boyutu, bir kişinin başarı odaklı, güvenilen, disiplinli ve sorumluluk sahibi olma derecesini açıklamaktadır (McCrae ve John, 1992: 178). Dışadönüklük (Extraversion), çoğunlukla sosyal, diğer bireylerle birlikte olmaktan zevk alan, enerji dolu, mutlu, iddialı kişileri ifade ederken; içe dönük kişiler ise, fazla konuşmayı ve iletişim kurmayı sevmeyen, sessiz, genellikle yalnız olmayı seçen kişileri tanımlamaktadır (Bono vd., 2002). Uyumluluk (Agreeableness) boyutu; bireyin diğer bireylerle olan uyumunu ifade etmektedir (McCrae ve John, 1992: 178; Zellars vd., 2000: 1576). Uyumluluk faktörü yüksek kişiler güvenilir, yumuşak başl1, doğru, özverili, ağırbaşlı, iyimser, diğer bireylerle uzlaşmaya istekli, güvenilir, işbirlikçi kişiler olarak ifade edilmektedir (Bono, Boles, Judge ve Lauver, 2002). Duygusallık (neuroticism), duygusal denge olarak da tanımlanmaktadır. Duygusal bireyler; öfke, endişe, sinir, keder ve korku gibi negatif duyguları yaşamaya eğilimlidirler. $\mathrm{Bu}$ açıdan nevrotiklik düzeyi yüksek bireyler, kimseye güvenmeyen, içe dönük, öfkeli bireyler olarak tanınmaktadırlar (Costa ve McCrae, 1995).

Literatürde sosyal medya kullanım alışkanlıkları ile beş büyük kişilik özelliği ilişkisini ele alan çalışmalar incelendiğinde kişilik özelliklerinin sosyal medya kullanım alışkanlıkları üzerinde etkili olduğu görülmektedir (Ross vd., 2009; Correa vd., 2010; Amichai-Hamburger ve Vinitzky, 2010; Ryan ve Xenos, 2011; Moore ve McElroy, 2012; Hughes vd., 2012; Özgüven ve Mucan, 2012; Seidman, 2013; Çayırlı, 2017; Işı ve Kaptangil, 2018). Bununla birlikte sahte haberlere organik erişim ile kişilik özellikleri ilişkisini inceleyen bir adet çalışma bulunmaktadır (Buchanan ve Benson, 2019). Literatürde yapılan bu çalışmalar doğrultusunda aşağıdaki hipotezler geliştirilmiştir:

$\mathrm{H}_{1}$ : Katılımcıların dışa dönüklük düzeylerinin sahte haberlerin kabulü üzerinde anlamlı bir etkisi vardır.

$\mathrm{H}_{2}$ : Katılımciların nevrotiklik düzeylerinin sahte haberlerin kabulü üzerinde anlamlı bir etkisi vardır. 
$\mathrm{H}_{3}$ : Katılımcıların uyumluluk düzeylerinin sahte haberlerin kabulü üzerinde anlamlı bir etkisi vardır.

$\mathrm{H}_{4}$ : Katılımcıların sorumluluk düzeylerinin sahte haberlerin kabulü üzerinde anlamlı bir etkisi vardır.

$\mathrm{H}_{5}$ : Katılımcıların deneyime açıklık düzeylerinin sahte haberlerin kabulü üzerinde anlamlı bir etkisi vardır.

\section{2. Öz Yeterlilik}

Öz yeterlilik kavramı, sosyal öğrenme teorisini ortaya atan Bandura (1986) tarafından; kişinin amaçlanan bir performansı gösterebilmesi açısından çevresel şartları düzenleyerek, kendisinde gerekli davranışları sergileme gücünü bulacağına ilişkin bir inanç olarak ifade edilmektedir. Başka bir ifadeyle, öz yeterlilik, kişinin bir durum veya olay karşısında göstermek istediği performansa erişebilmek için yeterli olup olmadığına dair bireysel değerlendirmesini içermektedir. Literatürde öz yeterlilik kavramına ilişkin oldukça farklı tanımlara rastlanmaktadir.

Kuzgun (2011), öz yeterliliği; kişinin sahip olduğu kapasitenin, kabiliyetlerin, özgüvenin ve kendisine dair diğer özelliklerin, sergilenecek yeni davranışlarda performans sağlamasına yardımcı olabileceğine dair bireyin kendine yönelik olumlu tutumu olarak tanımlamaktadır. Bıkmaz (2002) ise öz yeterliliği, kişinin bir sorun ile karşı karşıya geldiğinde nasıl bir performans sergilemesi gerektiğine ve sorun ile ne kadar süre başa çıkabileceğine yönelik kabiliyeti olarak ifade etmektedir. Bireyin bir sorunla karşılaştığında kabiliyet ve kapasitesine ilişkin inancı düşükse, o sorun ile başa çıkması da zor olacaktır. $\mathrm{Bu}$ doğrultuda, kişinin çözüme ulaştırması gereken problemlerle karşılaşması durumunda, kendine olan inancının tam olması gerekmektedir. Bütün bu açıklamalar doğrultusunda öz yeterlilik, insanların bir eylemi gerçekleştirmeden önce o eylemde başarılı olabileceğine dair, kendisine yönelik bireysel yargı ve inançları olarak ifade edilebilir.

Literatürdeki çalışmalar incelendiğinde (Bandura, 1977; Stadjkovic ve Luthans, 1998; Bandura, 2001), kişilerdeki öz yeterlilik düzeyinin; yaptıkları tercihler, edindikleri deneyimler, kararlı olma durumu ve farklılaşan hayat şartlarına uyum sağlayabilmeleri aracılığıyla geliştiği görülmektedir. Bandura (1977)'nin ifadesine göre, kişilerin bir davranışı sergilemesi için var olması gereken tüm yetkinliklere sahip olmalarına karşın öz yeterlilik düzeylerinin yüksek olmaması, başarısızlığa uğramalarına ya da o eylemi gerçekleştirmekten çekinmelerine yol açmaktadır. Başka bir ifadeyle, kişilerin öz yeterlilikleri, bir davranışı gerçekleştirip gerçekleştiremeyeceklerinden çok, başarılı olup olamayacaklarına dair algıları aracılığıyla biçimlenmektedir. Yani insanlar, normal şartlarda sergileyebilecekleri performansı değişen hayat şartları nedeniyle sergileyemeyebilirler. Stadjkovic ve Luthans (1998)'a göre aslında gerekli yetenek ve kapasiteye sahip olan kişiler, yaşam koşulları neticesinde duydukları şüpheden dolayı sorunlar yaşayabilmektedirler. Bandura (1977)'ya göre bu durum kişilerin kendilerine dair öz yeterlilik algılarının yeterli olmamasından kaynaklanmaktadır. Öz yeterlilik, kişilerin hayatlarının ilk dönemlerinden şu an içinde bulundukları sürece kadar gelişimini sürdüren bireysel bir inanç mekanizmasıdır. Bireyin öz gelişiminin hayatı boyunca devam ettiği düşünülürse, kişilerin öz yeterlilik inançlarının da çocukluk döneminden yetişkinlik dönemine kadar tüm zamanlarda farklılık gösterebileceği ifade edilmektedir (Çubukçu ve Girmen, 2007).
Literatürde yapılan çalışmalar incelendiğinde, sosyal medya kullanımıyla öz yeterlilik ilişkisini inceleyen çalışmaların bulunduğu görülmektedir. Özkaya (2018) tarafından yapılan çalışmada lise öğrencilerinin sosyal medya bağımlılık düzeyleri ile öz yeterlilik düzeyleri arasında negatif yönlü anlamlı bir ilişki olduğu görülmektedir. Döş ve Özşahin (2019) tarafından yürütülen çalışmada ise, öğretmenlerin sosyal medya bağımlılık düzeyleri ile öz yeterlilik düzeyleri arasında negatif yönlü anlamlı bir ilişki olduğu görülmektedir. Avcılar ve Atalar (2019) ise çalışmaları neticesinde, üniversite öğrencilerinin sosyal medya bağımlılık düzeyi ile öz yeterlilik düzeyleri arasında negatif yönlü anlamlı bir ilişki olduğu sonucuna ulaşmışlardır. Soysal ve Aldal (2020) tarafından öğrencilerin eğitsel amaçlı sosyal ağ ve internet kullanımına yönelik öz-yeterlik algılarını ölçmek amacıyla yapılan çalışmada, internet kullanımına yönelik öz yeterliliğin öğrencilerin demografik özelliklerine göre anlamlı farklılık göstermediği tespit edilmiştir. Bununla birlikte alan yazını incelendiğinde sahte haberlerin öz yeterlilikle ilişkisini inceleyen bir adet çalışmaya rastlanmaktadır. Chen ve Cheng (2019) tarafindan yürütülen bu çalışmada öz yeterliliğin sahte haberlerin algılanan teşhisi üzerinde etkili olduğu sonucuna ulaşılmıştır. Bu çalışmalar doğrultusunda aşağıdaki hipotez geliştirilmiştir:

$\mathrm{H}_{6}$ : Öz yeterliliğin sahte haberlerin kabulü üzerinde anlamlı bir etkisi vardır.

\subsection{Sosyal Medyada Yer Alan Sahte Haberlerin Kabulü ve Yayılması}

Yeni medyanın kontrol etmesi zor yapısı, alg1 yönetimi bakımından oldukça tehlikeli bir durum yaratmaktadır. Çünkü eş zamanlı olarak birden fazla mesaja maruz bırakılan sosyal medya kullanıcılarının sahteyle gerçeği ayırt etmesi ve algılaması gitgide daha da güçleşmektedir. Globalleşen medya kanallarında her türlü habere ya da bilgiye istenildiği zaman ulaşma olasılığı tanınması, bireylerin gereğinden fazla bilgi yüklenmelerine ve bir süre sonra körleşmelerine neden olmaktadır (Acar, 2013: 208). Sosyal medyada yer alan ve bilgiye ulaşmayı sağlayan kaynakların birçoğu, aslında kullanıcılar aracılığıyla oluşturulmakta ve bu kaynakların çoğunda bir denetim mekanizması yer almamaktadır.

Cambridge sözlüğüne göre sahte haber; "kişilerin görüşleri üzerinde etki yaratmak amaciyla internet ya da diğer medya araçlarını kullanarak yayılan haber gibi görünen düzmece, sahte hikâyeler" olarak ifade edilmektedir (dictionary.cambridge.org). Sahte haberlerle ilgili araştırma yapan Allcott ve Gentzkow (2017: 213) ise bu haberleri, bilinçli olarak insanları yanlıș bilgilendirmek amacıyla üretilmiş, yanıltıcı olduğu doğrulanabilen haberler şeklinde tanımlamaktadır.

Sahte haberlerin engellenemediği günümüz pazarlama dünyasında, markalar ve firmalar da yanıltıcı haberleri ve hırsızlığı engellemek amacıyla çeşitli yöntemlere başvurmaktadırlar. Sahte haberler, izleyiciyi aldatma niyetiyle kasıtlı olarak yanlış bilgi veren haberler olarak tanımlanmasının yanında (Horne ve Adali, 2017; Bakir ve McStay, 2018; Kumar ve Shah, 2018), dezenformasyon olarak da bilinmektedir (Hannah vd., 2015). Bu yanıltıcı haberler; markalar açısından ciddi bir tehdit oluşturmakta ve markalar sahte haberlerden çeşitli şekillerde etkilenmektedirler (Berthon ve Pitt, 2018). Aşağıda sahte haberlerle ilgili yapılan bazı çalışmalara yer verilmiştir. 
Marchi (2012) tarafından gerçekleştirilen çalışmanın sonuçları, haber kaynaklarına erişimin güncel yollarını ve gençlerin resmi haber sitelerindense sosyal medya platformlarından haberlere ulaşmayı tercih ettiklerini göstermektedir. Balmas (2014) çalışmasında, verimsizlik, yabancılaşma ve sinizm duygularını beslemede sahte haber izlemenin dolaylı olumlu etkisine dair kanıtlar sunmaktadır. Zhang vd. (2016) sahte haberlerin, çevrimiçi tüketici değerlendirmelerinin güvenilirliğine ciddi şekilde zarar verebildiğini tespit etmişlerdir. Ren vd (2017) tarafindan kaleme alınan makalenin amacı, müşterilerin satın alma niyetlerini etkilemede çevrimiçi sahte değerlendirmenin etkilerini incelemektir. Zubiaga vd. (2017) sahte haber sınıflandırma sistemlerinin geliştirilmesine yönelik yapılan çalışmaları özetlemiş ve söylentilerin tespiti ve çözümlenmesi için sosyal medya madenciliğinde gelecekteki araştırmalar için önerilerde bulunmuşlardır. Koohikamali ve Sidorova (2017) tarafından yürütülen araştırmanın bulguları, sosyal ağ sitelerini kullanmaya yönelik tutumun ve sosyal ağ siteleri ile ilgili bilgileri yeniden paylaşma niyetinin algılanan bilgi kalitesinden (zevk, alaka düzeyi ve güvenilirlik) etkilendiğini; ayrıca risk alma eğilimi ve keyfin, sosyal ağ siteleri hakkındaki bilgileri olumlu yönde yeniden paylaşma niyetini etkilediğini göstermektedir. Davis ve Proctor (2017), Facebook ve diğer çevrimiçi medya kuruluşlarının, sahte haberleri tespit etmek ve yayılmasını azaltmak için stratejiler geliştirmeye başladıklarından söz etmiştir.

Riberiro vd (2017) tarafindan yürütülen çalışmada, çevrimiçi sosyal ağların, haberleri geleneksel medya teknolojilerinden önemli ölçüde farklı bir yapıda sundukları ve birçok kişinin haber tüketim alışkanlıklarını değiştirdikleri vurgulanmıştır. Tandoc Jr vd. (2018) ise çalışmalarında, sahte haberlerle ilgili yapılan tanımları gerçekler ve aldatma seviyeleri olmak üzere iki grup altında toplamışlardır. Jang ve Kim (2018)'in çalışmalarından elde edilen sonuçlar, partizan kimliğinin, sahte haberlere karşı sosyal isteksizliğin ve dış politik etkinliğin üçüncü şahıs algısının olumlu belirleyicileri olduğunu göstermiştir. Nelson ve Taneja (2018) tarafindan gerçekleştirilen araştırmanın bulguları, 2016 başkanlık seçimlerinden önce ve sonra gelen aylarda mobil ve masaüstü platformlardaki çevrimiçi ziyaret verilerinin incelenmesi 1şığında, sahte haber izleyicisinin küçük ve sadakatsiz bir grup internet kullanıcısından oluştuğunu göstermektedir. Vosoughi vd. (2018) sahte haberlerin gerçek haberlerden daha güncel olduğunu ve insanların güncel bilgileri paylaşma olasılıklarının daha yüksek olduğunu tespit etmişlerdir. Visentin, Pizzi ve Pichierri (2019) tarafından yürütülen araştırmanın bulguları; haberlerin nesnel doğruluğunun markaya yönelik davranışsal niyetler (yani satın alma, ağızdan ağıza yayma veya markanın mağazasını ziyaret etme niyeti) üzerinde doğrudan bir etkisi olmadığını; sahte haberlerin davranışsal niyetler üzerindeki etkisinde, insanların haberlerin güvenilirliğine ilişkin algılarının aracılık ettiğini ve bu sonucun da kaynakların algılanan güvenilirliğini, marka güvenini ve sonunda markaya yönelik tutumları etkilediğini göstermektedir.

Talwar vd. (2019) ise çalışmalarında, çevrimiçi güvenin, kendini ifşa etmenin, kaçırma korkusunun (FoMO) ve sosyal medya yorgunluğunun, sahte haberlerin (kasitlı olarak) paylaşılmasıyla olumlu bir şekilde ilişkili olduğunu; buna karşılık, sosyal karşılaştırmanın sahte haberlerin paylaşılmasıyla olumsuz bir ilişkisi olduğunu vurgulamaktadırlar. Buchanan ve Benson (2019) tarafindan yürütülen çalışmada, güvenilir kaynaklardan gelen mesajların yayılma olasılığı daha yüksek olduğundan, mesaj kaynağının genel organik erişim üzerinde etkili olduğu sonucuna ulaşılmıştır. Bunun yanında, risk eğiliminin organik erişimi etkilemediği ve Beş Büyük Kişilik özelliğinden yalnızca "Uyumluluk" boyutunun, organik erişim üzerinde istatistiksel olarak anlamlı bir etkiye sahip olduğu sonucuna ulaşılmıştır. Nyilasy (2019) ise çalışmasında, sahte haberleri olumsuz bir kitle ikna biçimi olarak tanımlamakta; pazarlama iletişimi alanı için sahte haberlerin önemini vurgulamakta ve etkili müdahalelerin geliştirilmesi için araştırmacılara tavsiyelerde bulunmaktadır. Chen ve Cheng (2019) çalışmaları neticesinde, öz-yeterliliğin ve medya güveninin, tüketicilerin sahte haberler hakkındaki ikna bilgisini önemli ölçüde öngördüğünü; sahte haberlerin ikna bilgisinin, tüketicilerin sahte haberlerin algılanan teşhisini ve daha sonra marka güvenini önemli ölçüde etkilediğini; ayrıca, sahte haberlerin ikna bilgisinin, öz yeterliliğin sahte haberlerin algılanan teşhisi ve marka güveni üzerindeki etkilerine aracılık ettiğini ortaya koymuşlardır. Mills ve Robson (2019) tarafından kaleme alınan ve hikâye anlatımını bir kriz yönetimi stratejisi olarak öneren bu teorik çalışma; marka yöneticilerine sahte haberlerin, marka için kritik risk oluşturabileceği durumlarda, sahte haber krizlerine tepkilerini bildirmek için bir rehber niteliğindedir.

Flostrand, Pitt ve Kietzmann (2019) tarafından yürütülen nitel çalışmada, sahte haberlerin marka yönetimi üzerindeki etkisinin arttığı konusunda, katılımcıların yüksek oranda fikir birliği gösterdiği bulgusuna ulaşılmıştır. Ayrıca çalışma, yalan haberlerin giderek artan bir fenomen olduğunu; hizmet markalarının en çok risk altında olduğunu; pazarlama yöneticilerinin sahte haber azaltma stratejilerini iyileştirmeleri gerektiğini vurgulamaktadır. Peterson (2019), teorik bir özellik taşıyan çalışmasında, sahte haberlerin önemini ve işletmeler ile hükümetler gibi kurumların bu süreçteki rolünü vurgulamaktadır. Çalışmada, marka yöneticilerine, markalarının bütünlüğünü korumak için hızla değişen günümüz dünyasında, markayı destekleyen personelin yeteneklerine esneklik kazandırmak ve sahte haberlere uygun yanıtlar vermek suretiyle, sahte haberlerin neden olduğu istenmeyen durumlardan kaçınma olasılıklarını artırmaları tavsiye edilmektedir. De Regt, Montecchi ve Ferguson (2019) tarafından sağlık ve güzellik endüstrisinde üç örnek vaka incelemesi aracılığıyla gerçekleştirilen araştırma neticesinde, sahte haberlerin yayılmasına katkıda bulunan yedi pazarlama taktiği belirlenmiştir. Ayrıca çalışma, sahte haberlerin nasıl yayıldığını daha iyi anlayarak marka yöneticilerinin, şirket politikalarını eş zamanlı olarak iyileştirebileceklerini, satışları teşvik edebileceklerini ve tüketicilerin markaya olan güvenini güçlendirebileceklerini vurgulamaktadır. Borges-Tiago vd. (2020), kullanıcıların sahte haberlere yönelik tutumlarının Avrupa ülkeleri arasında farklılık gösterdiğini ortaya koymuşlardır. Wisker (2020), kişinin ahlaki kurallarını, inancını ve değerlerini ihlal eden sahte haberlerin öfke ve marka nefretine neden olabileceğini; dindarlığın ise, öfke ve marka nefreti arasında aracı ilişki oluşturduğunu belirtmektedir. Kiraz (2020) nitel araştırma yönteminden yararlandığı çalışmasında, sahte haber yayılımında insan faktörünün ve psikolojisinin ne kadar önemli olduğu üzerinde durmuştur.

Rampersad ve Althiyabi (2020) çalışmalarında, kültürün sahte haberlerin kabulünün doğrudan bir belirleyicisi olmadığını ancak sahte haberlerin kabulü ve kullanma niyetleri üzerinde dolaylı etkilerinin bulunduğunu ortaya koymuşlardır. Ayrıca, sahte haberlerin kabulünün de, sahte haberleri kullanma ve 
paylaşma niyeti üzerinde önemli ve doğrudan pozitif etkiye sahip olduğunu ifade etmişlerdir. Literatürde yapılan bu çalışmalar incelendiğinde sosyal medyada yer alan sahte haberlerin markalar ve firmalar açısından ne kadar önemli olduğu ve pazarlama uygulayıcılarının marka imajı ve marka değerini korumak adına, bu haberlerin üretilmesi ve yayılmasıyla mücadele etmeleri gerektiği görülmektedir. Sosyal medyada yer alan haberlerin kullanıcılar tarafindan kabul edilmesi ve yeterince araştırılıp doğrulanmadan paylaşılması da markalar açısından büyük tehdit oluşturmaktadır. Rampersad ve Althiyabi (2020) tarafindan yürütülen çalışmada, sosyal medyada yer alan sahte haberleri kabul edip etmemenin, bu haberleri kullanma niyeti üzerinde etkili olduğu sonucuna ulaşılmıştır. Bu doğrultuda, aşağıda yer alan çalışmanın son hipotezi geliştirilmiştir:

$\mathrm{H}_{7}$ : Sahte haberlerin kabulünün sahte haberleri kullanma niyeti üzerinde anlamlı bir etkisi vardır.

\section{Araştırmanın Yöntemi}

Araştırmanın ana kütlesini Türkiye genelinde bulunan 18 yaş ve üzeri sosyal medya kullanıcıları oluşturmaktadır. Örneklem oluşturulurken "Kolayda Örnekleme" yöntemi kullanılmıştır. Örneklem sayısı Yazıcıŏ̆lu ve Erdoğan (2004) "Örneklem Büyüklükleri” tablosuna göre belirlenmiştir. Tabloya göre bu genişlikteki bir ana kütle için en az 384 kişinin örneğe dâhil edilebileceği belirtilmektedir. $\mathrm{Bu}$ çalışmada ise, 408 tüketici üzerinde anket uygulaması yürütülmüştür. Çalışmada çevrimiçi anket yöntemi kullanılmış olup, anket çalışması Google Form uygulaması üzerinden gerçekleştirilmiştir. Elde edilen veriler SPSS paket programı aracılığıyla analiz edilmiştir.

Anket formunun birinci bölümünde katılımcıların sosyal medya kullanım alışkanlıklarına ve beş büyük kişilik özelliğine ilişkin, ikinci bölümde sosyal medyadaki sahte haberleri kabul etme ve kullanma niyeti ile öz yeterliliğe ilişkin, üçüncü bölümde ise katılımcıların demografik özelliklerine ilişkin sorular bulunmaktadır. Beş Faktör Kişilik Ölçeği Benet-Martinez ve John (1998) tarafından geliştirilmiştir. Ölçekte 44 madde yer almaktadır. Boyutlar; dişa dönüklük (8 madde), uyumluluk (9 madde), sorumluluk (9 madde), deneyime açıklık (10 madde) ve nevrotiklik (8 madde) olarak isimlendirilmiştir. Schmitt vd. (2007) tarafından yürütülen uluslararası bir çalışmanın Türkiye ile ilgili kısmında ölçek Türkçe'ye uyarlanmıştır. Sahte haberlerin kabulü ve kullanma niyeti ile ilgili 8 adet ifade, Rampersad ile Althiyabi (2020) tarafından kullanılan ölçekten uyarlanarak hazırlanmıştır. Öz yeterlilik ifadeleri ise, Wei vd. (2010) tarafından geliştirilen ve Chen ve Cheng, Y. (2019) tarafından uyarlanan ölçekten yararlanılarak hazırlanmıştır. İkinci bölümde yer alan ifadeler 5'li likert tipi ölçek kullanılarak hazırlanmıştır.

Anket çalışması Erciyes Üniversitesi Sosyal ve Beşeri Bilimler Etik Kurulu'ndan 26.01.2021 tarihli 14 sayı numaralı Etik Kurul Onay Belgesinin alınmasının ardından 01.02.2021 - 01.03.2021 tarihleri arasında uygulanmıştır. Katılımcılara anket formunun öncesinde 'Aydınlatılmış Onam Formu' sunulmuş ve anket uygulamasına katılımın tamamen gönüllülük esasına dayalı olduğu konusunda bilgilendirme yapılmıştır.

\subsection{Araştırmanın Modeli}

$\mathrm{Bu}$ araştırmanın amacı tüketicilerin kişilik özelliklerinin ve öz yeterliliklerin sosyal medyada paylaşılan sahte haberlerin kabulü ve bu haberleri kullanma niyeti üzerindeki etkisini incelemektir. Araştırmanın amacı doğrultusunda araştırmanın modeli aşağıdaki şekilde oluşturulmuştur.

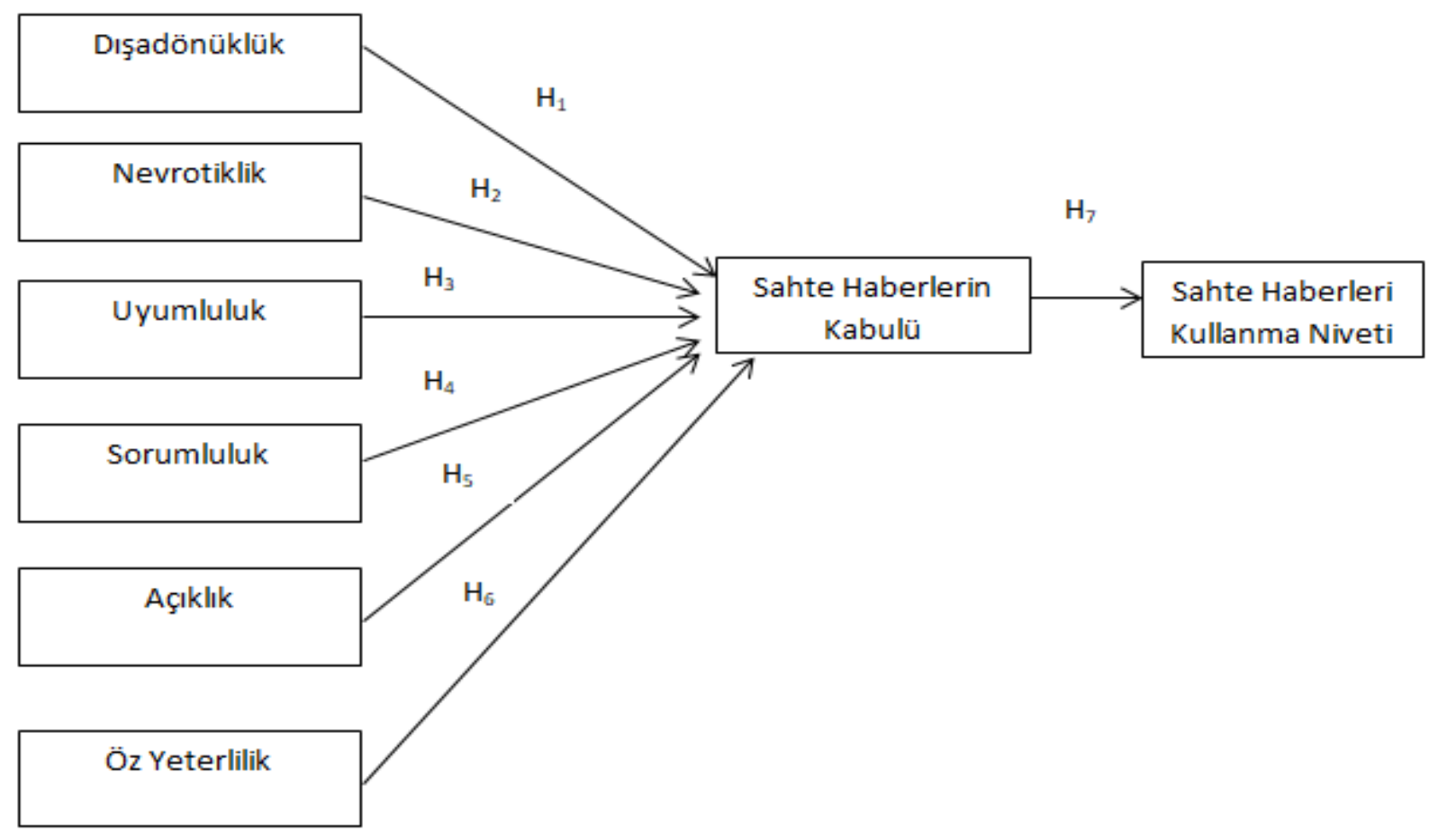

Şekil 1. Araştırmanın Modeli 


\subsection{Verilerin Analizi}

Verilerin normal dağılım gösterip göstermediğini incelemek amacıyla Kolmogorov-Smirnov testi uygulanmıştır. Daha sonra ise, ifadelerin çarpıklık ve basıklık değerleri incelenmiştir. Ölçeklerin çarpıklık ve basıklık değerleri incelendiğinde +2 ile 2 değerleri arasında yer aldıkları görülmektedir. $\mathrm{Bu}$ bilgiler ışığında verilerin normal dağılım gösterdiği sonucuna ulaşılmaktadır (George ve Mallery, 2010). Ardından, katılımcıların demografik özelliklerine ilişkin frekans analizine ve katılımcıların sosyal medya alışkanlıklarına ilişskin ifadelere yönelik betimleyici istatistiklere yer verilmiştir. Ölçeklerin güvenilirlik analizinin yapılmasından sonra araştırmanın hipotezlerini test etmek amaciyla korelasyon ve regresyon analizleri yapılmıştır. Veriler SPSS istatistik paket programı aracılığıyla analiz edilmiştir.

\subsection{Araştırmanın Bulguları ve Değerlendirilmesi}

Araştırmada yapılan analizler ve elde edilen bulgular aşağıda yer alan ilgili tablolarda verilmiş ve yorumlanmıştır.

Katılımcıların demografik özelliklerini incelemek amaçlı yapılan frekans analizi sonuçları Tablo 1'de gösterilmektedir.

Tablo 1. Demografik Özelliklere Göre Dă̆ılım

\begin{tabular}{|c|c|c|c|}
\hline \multicolumn{2}{|c|}{ Demografik Özellikler } & n & \% \\
\hline \multirow{4}{*}{ Yaş } & 26 ve alt1 & 156 & 38,2 \\
\cline { 2 - 4 } & $27-32$ & 34 & 8,3 \\
\cline { 2 - 4 } & $33-38$ & 52 & 12,7 \\
\cline { 2 - 4 } & $39-44$ & 59 & 14,5 \\
\cline { 2 - 4 } & $45-50$ & 64 & 15,7 \\
\cline { 2 - 4 } & 51 ve üzeri & 43 & 10,5 \\
\hline \multirow{4}{*}{ Gelir } & Toplam & $\mathbf{4 0 8}$ & $\mathbf{1 0 0}$ \\
\cline { 2 - 4 } & 2000 ve altı & 124 & 30,4 \\
\cline { 2 - 4 } & $2001-3000$ & 33 & 8,1 \\
\cline { 2 - 4 } & $3001-4000$ & 27 & 6,6 \\
\cline { 2 - 4 } & $4001-5000$ & 42 & 10,3 \\
\cline { 2 - 4 } & $5001-6000$ & 17 & 4,4 \\
\cline { 2 - 4 } & 6001 ve üzeri & 165 & 40,2 \\
\cline { 2 - 4 } & Toplam & $\mathbf{4 0 8}$ & $\mathbf{1 0 0}$ \\
\hline
\end{tabular}

Katılımcıların demografik özelliklere göre dağılımları incelendiğinde araştırmaya katılan 408 tüketicinin \%60'ının kadın, \%40'ının erkek; \%38,2'sinin 26 yaş ve altında; $\% 40,2$ 'sinin gelirinin $6001 \mathrm{TL}$ ve üzerinde, \%30,4'ünün gelirinin $2000 \mathrm{TL}$ ve altında; $\% 47,8$ 'inin ise lisans programı mezunu olduğu görülmektedir. Demografik özellikler tablosu incelendiğinde, bazı kategorilerde homojen dağılım olmadığı

Tablo 2. Sosyal Medya Kullanım Alışkanlıklarına Göre Dă̆ılım

görülmektedir. $\mathrm{Bu}$ durum katılımcıların kolayda örnekleme yöntemiyle seçilmiş olmasının bir sonucu olarak karşımıza çıkmaktadır.

Katılımcıların sosyal medya kullanım alışkanlıklarına yönelik yapılan frekans analizi sonuçları Tablo 2'de yer almaktadir.

\begin{tabular}{|l|c|}
\hline En Çok Kullanılan Sosyal Medya Platformları & n \\
\hline Instagram & 272 \\
\hline Facebook & 28 \\
\hline Twitter & 37 \\
\hline Youtube & 54 \\
\hline Tiktok & 3 \\
\hline
\end{tabular}

\begin{tabular}{|l|l|}
\hline Diğer & 14 \\
\hline Sosyal Medya Platformlarını Ziyaret Sıklı̆̆ı & $\mathbf{n}$ \\
\hline $5-10$ (akika & 57
\end{tabular}

\begin{tabular}{|l|l}
\hline $5-10$ dakikada bir kez & 57 \\
\hline Saatte bir kez & 13 \\
\hline
\end{tabular}

\begin{tabular}{|l|l}
\hline İki üç saatte bir kez & 94
\end{tabular}

\begin{tabular}{|l|l}
\hline Günde birkaç kez & 99 \\
\hline
\end{tabular}

\begin{tabular}{|l|l|}
\hline Haftada birkaç kez & 9 \\
\hline
\end{tabular}

Ayda birkaç kez

Katılımciların sosyal medya platformlarını ziyaret s1klıkları incelendiğinde \%14'ünün 5-10 dakikada bir kez; \%33,3'ünün saatte bir kez; \%23'ünün iki üç saatte bir kez; \%24,3'ünün ise günde birkaç kez sosyal medyada bulunduğu görülmektedir. e-ISSN: 2148-2683

Sonuçlar katılımcıların büyük çoğunluğunun gün içerisinde sıklıkla sosyal medya platformlarını ziyaret ettiğini göstermektedir. Katılımcıların en çok kullandıkları sosyal medya platformları incelendiğinde, \%66,7'sinin Instagram; \%6,9'unun 
Facebook; \%9,1'inin Twitter; \%13,2'sinin ise Youtube kullandıkları sonucuna ulaşılmaktadır. Cevaplayıcıların sosyal medya platformları arasında en çok Instagram'ı kullanmaları araştırmanın önemli bulgularından biridir. Demografik özelliklerin ve katılımcıların sosyal medya platformu kullanımına dair alışkanlıklarının incelenmesi amacıyla yapılan frekans analizleri ve betimleyici istatistiklerin ardından, araştırmada kullanılan ölçekler için güvenilirlik analizi yapılmıştır.

Araştırmada kullanılan ölçeklere yapılan güvenilirlik analizi sonucunda elde edilen Cronbach Alpha Katsayıları Tablo 3'te gösterilmektedir.

Tablo 3. Araştırmada Kullanılan Ölçeklerin Güvenilirlik Değerleri

\begin{tabular}{|l|r|}
\hline Ölçekler & Cronbach Alpha Katsayısı \\
\hline Deneyime Açılık &, 756 \\
\hline Dışa Dönüklük &, 843 \\
\hline Nevrotiklik &, 814 \\
\hline Sorumluluk &, 771 \\
\hline Uyumluluk &, 619 \\
\hline Sahte Haberlerin Kabulü &, 654 \\
\hline Sahte Haberleri Kullanma Niyeti &, 720 \\
\hline Öz Yeterlilik &, 743 \\
\hline
\end{tabular}

Yukarıda beş büyük kişilik özelliğine ait alt boyutlar (deneyime açıklık, dışa dönüklük, nevrotiklik, sorumluluk, uyumluluk); sahte haberlerin kabulü, sahte haberleri kullanma niyeti ve öz yeterlilik ölçeklerine ait Cronbach Alpha katsayıları verilmiştir. Sahte haberlerin kabulü ölçeğinin güvenilirlik katsayısının düşük çıkmasına neden olan iki ifade analiz kapsamından çıkarılmıştır. Yapılan güvenilirlik analizi sonucu ortaya çıkan Alpha katsayıları incelendiğinde, anket formunda yer alan ölçeklerin güvenilir olduğu sonucuna ulaşılmaktadır.
Ölçeklerin güvenilir olduğunu söylemek için Alpha değerinin 0,60 ve üzerinde olması yeterli kabul edilmektedir (Özdamar, 2004).

Öte yandan, araştırmanın değişkenleri arasındaki ilişkileri incelemek için korelasyon analizi yapılmıştır. Korelasyon katsayıları değişkenler arasındaki ilişkilerin derecesini, \%1 ya da \%5 düzeyindeki anlamlılığını ve oluşan ilişkilerin pozitif ya da negatif yönlülüğünü göstermektedir.

Tablo 4. Değişkenler Arasındaki Çoklu Korelasyon Analizi Sonuçları

\begin{tabular}{|c|c|c|c|c|c|c|c|c|}
\hline 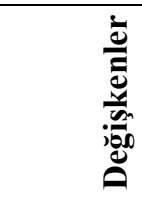 & 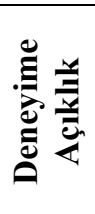 & 装 & 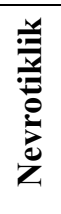 & 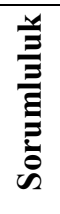 & 昙 & 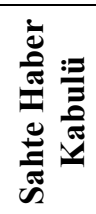 & 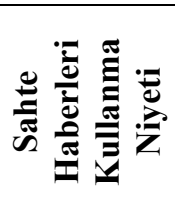 & 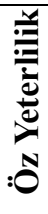 \\
\hline$\dot{0}$ & 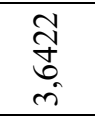 & $\begin{array}{l}\infty \\
\underset{f}{\sim} \\
\text { ஸे }\end{array}$ & $\frac{m}{m}$ & $\begin{array}{l}\bar{\sigma} \\
\text { aे } \\
\text { n. }\end{array}$ & $\begin{array}{l}\text { त̃ } \\
\text { ळू } \\
\text { m. }\end{array}$ & 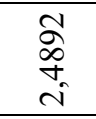 & $\begin{array}{l}\overline{0} \\
\text { ñ } \\
\text { n}\end{array}$ & $\begin{array}{l}\frac{0}{0} \\
\frac{0}{2} \\
m\end{array}$ \\
\hline- & I & $\stackrel{\stackrel{*}{*}}{\stackrel{*}{\sim}}$ & $\begin{array}{l}\stackrel{*}{*} \\
\stackrel{\text { N }}{\text { N }}\end{array}$ & $\begin{array}{l}* \\
\stackrel{*}{*} \\
\stackrel{0}{0} \\
\text { ?n }\end{array}$ & $\frac{*}{*}$ & $\stackrel{+}{+}_{i}^{\infty}$ & $\begin{array}{l}\text { * } \\
\stackrel{*}{0} \\
\stackrel{\sim}{N} \\
\text { ปn }\end{array}$ & $\stackrel{*}{\stackrel{*}{\stackrel{*}{N}}}$ \\
\hline$N$ & & I & $\begin{array}{l}* \\
\stackrel{*}{*} \\
\underbrace{\prime}_{n}\end{array}$ & $\begin{array}{l}* \\
\stackrel{*}{*} \\
\stackrel{n}{n}\end{array}$ & $\begin{array}{l}\stackrel{*}{*} \\
\stackrel{*}{\sigma} \\
\stackrel{\sigma}{\sigma}\end{array}$ & తి & $\begin{array}{l}\stackrel{*}{*} \\
\stackrel{*}{\infty} \\
\underline{n}\end{array}$ & 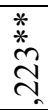 \\
\hline$\nabla$ & & & & I & $\begin{array}{l}* \\
* \\
* \\
i \\
t_{n}\end{array}$ & $\stackrel{*}{\stackrel{*}{=}}$ & 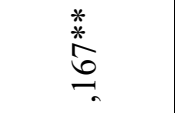 & $\begin{array}{l}* * \\
\stackrel{*}{*} \\
\stackrel{2}{n}\end{array}$ \\
\hline in & & & & & ' & 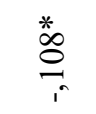 & $\frac{n}{0}$ & $\stackrel{*}{*}$ \\
\hline b & & & & & & 1 & $\begin{array}{l}\stackrel{*}{*} \\
\stackrel{*}{m} \\
\text { n. }\end{array}$ & $\mathscr{\infty}_{i}^{\infty}$ \\
\hline$r$ & & & & & & & 1 & $\begin{array}{l}\text { * } \\
\text { *ैo } \\
\text { ᄋ }\end{array}$ \\
\hline
\end{tabular}


Tablo 4'teki analiz sonuçlarına göre, değişkenler arasında çoğunlukla \%1 anlamlılık düzeyinde ilişkiler olduğu belirlenmiştir. Korelasyon analizi sonuçlarına göre, beş faktör kişilik özelliklerinden nevrotiklik ile sahte haberlerin kabulü arasında anlamlı ve negatif yönlü bir ilişki vardır ( $\mathrm{r}=-, 184$; $\mathrm{p}<, 01)$. Ayrıca sorumluluk ve uyumluluk kişilik özellikleriyle de sahte haberlerin kabulü arasında anlamlı ve negatif yönlü bir ilişki vardır $(\mathrm{r}=-, 113, \mathrm{p}<, 05 ; \mathrm{r}=-, 108 ; \mathrm{p}<, 05)$. Ancak deneyime açıklık ve dışa dönüklük değişkenleriyle sahte haberlerin kabulü arasında anlamlı bir ilişski tespit edilmemiştir. Bununla birlikte sahte haberlerin kabulü ile bu haberleri kullanma niyeti arasında anlamlı ve pozitif yönlü bir ilişki olduğu sonucuna ulaşılmaktadır ( $\mathrm{r}=, 306 ; \mathrm{p}<, 01)$. Başka bir deyişle, katılımcıların sahte haberleri kabul etme düzeyleri arttıkça, bu haberleri yayma ve kullanma niyetleri de artış göstermektedir. Bununla birlikte, öz yeterlilikle sahte haberleri kullanma niyeti arasında anlamlı ve pozitif yönlü bir ilişki tespit edilmiştir $(r=, 306 ; p<, 01)$.

Regresyon analizi, bağımlı bir değişken ile bu bağımlı değişken üzerinde etkisi olduğu düşünülen bağımsız değişken veya değişkenler arasındaki ilişkinin bir model ile açıklanmasını ifade eder. Beş büyük kişilik özelliği ve öz yeterlilik bağımsız değişkenlerinin bağımlı değişken olan sahte haberlerin kabulü üzerindeki etkinlik düzeylerini ortaya çıkartmak amacıyla çoklu regresyon analizi kullanılmıştır. Tablo 5'te regresyon analizi sonuçları gösterilmiştir. Analiz sonucunda, $R$ değerinin 0,265 ve $\mathrm{R}^{2}$ değerinin ise 0,07 olduğu ortaya çıkmıştır. Yine, $F$ değerinin $\% 1$ anlamlılık düzeyinde 5,066 olduğu tespit edilmiştir. Analizlerden regresyonun güvenilir olduğu anlaşılmaktadır.

Tablo 5. Sahte Haberlerin Kabulünü Etkileyen Değişkenlerin Çoklu Regresyon Analizi Sonuçları

\begin{tabular}{|l|l|l|l|l|}
\hline Değişkenler & $\mathbf{B}$ & $\mathbf{S H}$ & $\mathbf{\beta}$ & $\mathbf{p}$ \\
\hline Deneyime Açıklık &,- 030 &, 061 &,- 027 &, 623 \\
\hline Dışa Dönüklük &, 196 &, 053 &, $232^{* *}$ &, 000 \\
\hline Nevrotiklik &,- 177 &, 047 &,$- 213^{* *}$ &, 000 \\
\hline Sorumluluk &,- 083 &, 063 &,- 081 &, 188 \\
\hline Uyumluluk &,- 109 &, 073 &,- 085 &, 137 \\
\hline Öz Yeterlilik &,- 051 &, 042 &,- 062 &, 225 \\
\hline Sabit & 3,404 &, 294 & & \\
\hline Not: Düz. $\mathbf{R}^{2}=\mathbf{0 , 0 7} ; \mathbf{F}=\mathbf{5 , 0 6 6} ; * \boldsymbol{*} \mathbf{p}<\mathbf{0 , 0 1}$ & \multicolumn{2}{|l}{} \\
\hline
\end{tabular}

Bu sonuçlara göre kişilik özellikleri ve öz yeterlilik ile sahte haberlerin kabulü arasındaki ilişki (Sahte Haberlerin Kabulü=3,404+0,196*D1şadönüklük-0,177*Nevrotiklik) şeklindedir. Regresyonun geçerli olması için gereken normallik Şartı sağlanmıştır. Çoklu bağlantı açısından bakıldığında, ilgili VIF değerlerinin 2'nin altında olduğu görülmüş ve çoklu bağlantı olmadığı sonucuna ulaşılmıştır. Oto-korelasyon açısından bakıldığında ise, elde edilen Durbin-Watson test istatistiği değerinin 2,064 olarak elde edilmesi, değişkenler arasında oto-korelasyonun olmadığını göstermektedir (Gürbüz ve Şahin, 2014).

Çoklu regresyon analizi sonuçları anlamlıdır. Düzeltilmiş $\mathrm{R}^{2}$ değeri 0,07 olarak bulunmuştur. $\mathrm{Bu}$ sonuç, sahte haberlerin kabulündeki $\% 7$ oranında varyansın kişilik özellikleri ve öz yeterlilik tarafından açıklandığını göstermektedir. Ancak, Tablo 5'deki Beta katsayıları incelendiğinde, sadece dışa dönüklük ve nevrotiklik kişilik özelliklerinin sahte haberlerin kabulü üzerinde anlamlı bir etkisi olduğu görülmektedir $(p<0,01)$. Diğer bağımsız değişkenler olan deneyime açıklık, sorumluluk, uyumluluk, ve öz yeterlilik değişkenlerinin bağımlı değişken olan sahte haberlerin kabulü üzerinde anlamlı bir etkisinin bulunmadığı görülmektedir. Regresyon analizi sonuçlarına göre, $\% 1$ anlamlılık düzeyinde ve $0,232 \beta$ katsayısı ile dışa dönüklük değişkeninin sahte haberlerin kabulü üzerinde anlamlı bir etkisi vardır şeklinde oluşturulan araştırma hipotezi kabul edilmiştir $\left(\mathrm{H}_{1}\right)$. Yani, bireylerin dışa dönük kişilik özellikleri taşımaları, sosyal medyada yer alan sahte haberleri kabul edip etmemelerini etkilemektedir. Yine, Tablo 7'deki analiz sonuçlarına göre, nevrotikliğin sahte haberleri kabul etme düzeyi üzerinde etkili olduğu ortaya çıkmıştır. Nevrotiklik bağımsız değişkeni \%1 anlamlılık düzeyinde ve $-0,213 \beta$ katsayısı ile sahte haberlerin kabulünü etkilemektedir. $\mathrm{Bu}$ sonuca göre, $\mathrm{H}_{2}$ hipotezi kabul edilmiştir. Bununla birlikte, deneyime açıklık, sorumluluk, uyumluluk ve öz yeterlilik değişkenlerinin sahte haberlerin kabulü üzerinde anlamlı bir etkiye sahip olmadığ ulaşılmış olup; $\mathrm{H}_{3}, \mathrm{H}_{4}, \mathrm{H}_{5}$ ve $\mathrm{H}_{6}$ hipotezleri reddedilmiştir.

Tablo 6'da sahte haberlerin kabulünün sahte haberleri kullanma niyeti üzerindeki etkisini inceleyen Regresyon analizi sonuçları gösterilmiştir. Analiz sonucunda, $\mathrm{R}$ değeri 0,334 ve $\mathrm{R}^{2}$ değeri ise 0,11 olduğu ortaya çıkmıştır. Yine, $\mathrm{F}$ değerinin $\% 1$ anlamlılık düzeyinde 51,123 olduğu tespit edilmiştir. Yapılan analizlerden regresyonun güvenilir olduğu anlaşılmaktadır.

Tablo 6. Sahte Haberleri Kullanma Niyetini Etkileyen Değişkene Ait Basit Doğrusal Regresyon Analizi Sonuçları

\begin{tabular}{|l|l|l|l|l|}
\hline & B & SH & $\boldsymbol{\beta}$ & $\mathbf{p}$ \\
\hline Sahte Haberlerin Kabulü &, 498 &, 070 &, $334^{* *}$ &, 000 \\
\hline Sabit & 2,038 &, 180 & & \\
\hline \multicolumn{2}{|l|}{ Not: Düz. $\mathbf{R}^{\mathbf{2}}=\mathbf{0 , 1 1 2} ; \mathbf{F}=\mathbf{5 1 , 1 2 3} ;{ }^{* *} \mathbf{p}<\mathbf{0 , 0 1}$} & & & \\
\hline
\end{tabular}

Sahte haberlerin kabulü ile sahte haberleri kullanma niyeti arasındaki ilişkiyi inceleyen regresyon denklemi (Sahte Haberleri Kullanma Niyeti $=2,038+0,498 *$ Sahte Haberlerin Kabulü) şeklindedir.Basit doğrusal regresyon analizinden elde edilen sonuç, sahte haberleri kullanma niyetindeki \%11 oranında varyansın sahte haberlerin kabulü tarafından açıklandığını göstermektedir. Tablo 6'daki Beta katsayısı incelendiğinde, sahte haberlerin kabulünün, sahte haberleri kullanma niyeti üzerinde 
anlamlı bir etkisi olduğu görülmektedir $(p<0,01)$. Regresyon analizi sonuçlarına göre, $\% 1$ anlamlılık düzeyinde ve $0,334 \beta$ katsayısı ile sahte haberlerin kabulü değişkeninin sahte haberleri kullanma niyeti üzerinde anlamlı bir etkisi vardır şeklinde oluşturulan araştırma hipotezi kabul edilmiştir $\left(\mathrm{H}_{7}\right)$.

\section{Tablo 7. Hipotez Testi Sonuçları}

\begin{tabular}{|l|c|}
\hline $\mathrm{H}_{1}:$ Katılımcıların dışadönüklük düzeylerinin sahte haberlerin kabulü üzerinde anlamlı bir etkisi vardır. & Kabul \\
\hline $\mathrm{H}_{2}$ : Katılımcıların nevrotiklik düzeylerinin sahte haberlerin kabulü üzerinde anlamlı bir etkisi vardır. & Kabul \\
\hline $\mathrm{H}_{3}:$ Katılımcıların uyumluluk düzeylerinin sahte haberlerin kabulü üzerinde anlamlı bir etkisi vardır. & Red \\
\hline $\mathrm{H}_{4}:$ Katılımcıların dürüstlük düzeylerinin sahte haberlerin kabulü üzerinde anlamlı bir etkisi vardır. & Red \\
\hline $\mathrm{H}_{5}:$ Katılımcıların açıklık düzeylerinin sahte haberlerin kabulü üzerinde anlamlı bir etkisi vardır. & Red \\
\hline $\mathrm{H}_{6}:$ Öz yeterliliğin sahte haberlerin kabulü üzerinde anlamlı bir etkisi vardır. & Kabul \\
\hline $\mathrm{H}_{7}:$ Sahte haberlerin kabulünün sahte haberleri kullanma niyeti üzerinde anlamlı bir etkisi vardır. & \\
\hline
\end{tabular}

Tablo 7'de yer alan hipotez testi sonuçları incelendiğinde, beş faktör kişilik özellikleri boyutlarından dışa dönüklük ve duygusal denge (nevrotiklik) boyutlarının sahte haberlerin kabulü üzerinde etkili olduğu; fakat deneyime açıklık, uyumluluk ve sorumluk boyutlarının etkili olmadığı tespit edilmiştir. Bununla birlikte, araştırma sonuçları öz yeterliliğin sahte haberlerin kabulü üzerinde anlamlı bir etkisinin bulunmadığını göstermektedir. Araştırmanın önemli bulgularından birisi de sahte haberlerinin kabulünün sahte haberleri kullanma niyeti üzerinde etkili olduğudur.

\section{Sonuç ve Öneriler}

Sahte haberlerin pazarlama dünyası üzerindeki etkileri incelendiğinde, markalar ve firmalar hakkında çıkan sahte haberlerin sosyal medya platformları aracılığıyla yayılmasının günümüz toplumunda endişe verici bir duruma geldiği görülmektedir. $\mathrm{Bu}$ doğrultuda bu çalışma, beş büyük kişilik özelliği ve öz yeterliliğin sahte haberlerin kabulü ve yayılması üzerindeki etkisini araştırmak amacıyla gerçekleştirilmiştir. Araştırma, kolayda örnekleme yöntemiyle belirlenen ve Türkiye genelinde sosyal medya platformlarını kullanan 408 tüketici üzerinde çevrimiçi anket yöntemi uygulanarak yapılmıştır. Araştırmada katılımcıların demografik özelliklerine ilişkin tanımlayıcı istatistiklere yer verildikten sonra, ölçeklerin güvenilirlik analizi yapılmış, son olarak da korelasyon ve regresyon analizleri uygulanmıştır.

Araştırmanın hipotezlerinin regresyon analizi aracılığıyla test edilmesi sonucunda elde edilen değerlere göre, beş büyük kişilik özelliği boyutlarından "dışa dönüklük" ve "nevrotiklik" boyutlarının sahte haberlerin kabulü üzerinde anlamlı bir etkisinin olduğu fakat "deneyime açıklık", "uyumluluk" ve "sorumluluk" boyutlarının anlamlı bir etkisinin bulunmadığ sonucuna ulaşılmıştır. Literatürde kişilik özellikleri ile sahte habere erişim arasındaki ilişkiyi içeren yalnızca bir adet çalışmaya rastlanmaktadır (Buchanan ve Benson, 2019). Bu çalışmada da, sadece uyumluluk boyutunun sahte haberlere organik erişim üzerinde etkili olduğu görülmektedir. Ancak bahsedilen çalışmada, kişilik özellikleri ile sahte haberlere organik erişim arasındaki ilişki incelenmiştir. Sahte haberlerin kabulünü ele alan bu çalışmada ise farklı sonuçlar elde edilmiştir. Bununla birlikte, öz yeterliliğin de sahte haberlerin kabulü üzerinde etkili olmadığı sonucuna ulaşılmıştır. İlgili yazında, öz yeterliliğin sahte haberlerin algılanan teşhisi üzerinde etkili olduğu bulgusuna ulaşan bir adet çalışma yer almaktadır (Chen ve Cheng, 2020). Fakat adı geçen çalışmada, öz yeterlilikle sahte haberlerin algılanan teşhisi arasındaki ilişki incelenmiştir. $\mathrm{Bu}$ nedenle, sonuçların benzerlik göstermediği düşünülmektedir. Sonuçların farklı çıkmasının olası başka bir sebebinin de, kültürel farklılıklardan kaynaklanabileceği düşüncesidir. Başka bir ülkede, katılımcıların uyumluluk veya öz yeterlilik düzeyleri sahte haberlerin kabulü üzerinde etkili olabilirken, ülkemizde dişa dönüklük ve nevrotiklik özellikleri daha etkili olabilmektedir. Araştırmanın diğer bir bulgusu ise sahte haberlerin kabulünün, sahte haberleri kullanma ve yayma niyeti üzerinde etkili olduğudur. Elde edilen bu bulgu, Rampersad ve Althiyabi (2020) tarafından elde edilen sonuçlarla benzerlik göstermektedir.

$\mathrm{Bu}$ çalışmanın sonuçları pazarlama yöneticilerine sahte haberlere ilişkin önemli bilgiler sunmaktadır. Tüketiciler, sosyal medyada markalara ilişkin yer alan ve hızla yayılan sahte haberlerden oldukça fazla etkilenmektedirler. Çalışmanın sonuçlarına göre, özellikle dışa dönüklük ve duygusal denge (nevrotiklik) özelliklerinin, sahte haberleri kabul etme düzeyi üzerinde anlamlı bir etkisi bulunmaktadır. Dışa dönük bireyler genellikle sosyal, insanlarla beraber olmaktan hoşlanan, istekli ve eyleme yönelik, sosyal, enerjik, neşeli, baskın, iddialı bireyleri ifade etmektedir. Bununla birlikte, dışadönük bireyler, özgüveni yüksek, aktif ve heyecan arayan bireylerdir. Duygusal bireyler ise; öfke, endişe, sinir, keder ve korku gibi negatif duyguları yaşamaya eğilimlidirler. Bu açıdan nevrotiklik düzeyi yüksek bireyler, kimseye güvenmeyen, içe dönük, öfkeli bireyler olarak tanınmaktadırlar Araştırmanın sonuçlarına göre, bir birey ne kadar dışa dönük olursa, sahte haberleri kabul etme oranı da o kadar artacaktır $(\mathrm{B}=, 196 ; \mathrm{p}<, 001)$; nevrotiklik düzeyi ne kadar artarsa da sahte haberleri kabul etme düzeyi kadar azalacaktır $(\mathrm{B}=-, 177 ; \mathrm{p}<, 001)$.

Pazarlama uygulayıcıları açısından, tüketici özelliklerinin anlaşılması ve bu doğrultuda sahte haberlere karşı mücadele etmeleri büyük öneme sahiptir. Teknolojinin gelişimi ve tüketim alışkanlıklarının farklılaşmasıyla birlikte, tüketicilerin sosyal medya alışkanlıkları da değişiklik göstermeye başlamıştır. Tüketiciler sosyal medyada markalar ve ürünlere dair yer alan her türlü haberi kabul etmekte ve hızla diğer bireylerle paylaşmaktadırlar. Araştırmanın bulgularından birisi de, sahte haberleri kolaylıkla kabul eden bireylerin; aynı zamanda, bu haberleri de hızla yayma eğiliminde olduklarına dairdir. Dolayısıyla, marka yöneticileri hitap ettikleri pazar bölümümün kişilik özelliklerini doğru tanımalı ve sahte haberlere karşı doğru şekilde stratejiler geliştirmelidir. Aksi takdirde, hızla yayılan sahte haber paylaşımı akımı, pazarlama dünyasında daha da tehlikeli bir hal almaya başlayacaktır. 
Araştırmanın en önemli kısıtı, çalışmada zaman ve maliyet sınırlamasının bulunması nedeniyle, kolayda örnekleme yöntemi kullanılmış olmasıdır. Gelecek çalışmalarda örneklem seçimi yapılırken tesadüfi örnekleme yöntemlerinden birisi kullanılabilir. Bunun yanında sosyal medyada yer alan sahte haberlerin kabulü ve yayılmasının tüketicilerin markaya duyduğu nefret, güven, bağlılık düzeyleri gibi farklı değişkenler üzerindeki etkisi de incelenebilir.

\section{Kaynakça}

Acar, O. N. (2013). Özgürlük Alanı Olarak Sunulan Sosyal Medya ve Taksim Gezi Parkı Eylemleri. Akdeniz İletişim Akdeniz Üniversitesi İletişim Fakültesi Dergisi, 20.

Allcott, H. and Gentzkow, M. (2017). Social Media and Fake News in the 2016 Election. Journal of Economic Perspectives, 31(2), 211-36.

Amichai-Hamburger, Y. and Vinitzky, G. (2010). Social Network Use and Personality. Computers in Human Behavior, 26, 1289-1295.

Avcılar, M. Y. ve Atalar, S. (2019). Narsistik Kişilik Özelliklerinin Sosyal Medya Bağımlılık Düzeyi Ve Gösterişçi Tüketim Eğilimleri Üzerine Etkisinin Tespiti. Uluslararası Toplum Araştırmaları Dergisi, 11(18), 13731407.

Bakir, V. and McStay, A. (2018), Fake News and the Economy of Emotions, Digital Journalism, 6(2), 154-175.

Balmas, M. (2014). When Fake News Becomes Real: Combined Exposure to Multiple News Sources and Political Attitudes of Inefficacy, Alienation, and Cynicism. Communication Research, 41(3), 430-454.

Bandura, A. (1977). Self-efficacy: Toward A Unifying Theory of Behovioral Change. Psychological Review, 84(2), 191-215.

Bandura, A. (1986). The Explanatory and Predictive Scope of Self-Efficacy Theory. Journal of Social and Clinical Psychology, 4(3), 359-373.

Bandura, A. (2001). Social Cognitive Theory: An Agentic Perpective. Annual Review of Psychology, 52, 1-26.

Benet-Martínez, V. and John, O. P. (1998). Los Cinco Grandes Across Cultures and Ethnic Groups: Multitrait-Multimethod Analyses of the Big Five in Spanish and English. Journal of Personality and Social Psychology, 75(3), 729.

Berthon, P.R. and Pitt, L.F. (2018), Brands, Truthiness and PostFact: Managing Brands in a Post-Rational World. Journal of Macromarketing, 38, 218-227.

B1kmaz, F. (2002). Fen Öğretiminde Öz Yeterlilik İnancı Ölçeği. Eğitim Bilimleri ve Uygulama, 1(2), 197-210

Bono, J. E., Boles, T. L., Judge, T. A. and Lauver, K. J. (2002). The Role of Personality in Task and Relationship Conflict. Journal of Personality, 70(3), 311-344.

Borges-Tiago, T., Tiago, F., Silva, O., Guaita Martínez, J. M. and Botella-Carrubi, D. (2020). Online Users' Attitudes Toward Fake News: Implications for Brand Management. Psychology and Marketing.

Buchanan, T. ve Benson, V. (2019). Spreading Disinformation on Facebook: Do Trust in Message Source, Risk Propensity, or Personality Affect the Organic Reach of "Fake News"? Social Media+Society, 5(4).

Burger, J. M. (2006). Kişilik. (Çeviren: İnan Deniz, E. Sarığlu). (1.Bask1). İstanbul: Kaktüs Yayınları.

Çayırlı, E. (2017). Sosyal medya kullanım özelliklerinin kişilik yapılanmaları, yaşam doyumu ve depresyon açısından incelenmesi, Yüksek Lisans Tezi, Işık Üniversitesi.
Chen, Z. F. and Cheng, Y. (2019). Consumer Response To Fake News About Brands on Social Media: The Effects of SelfEfficacy, Media Trust and Persuasion Knowledge on Brand Trust. Journal of Product and Brand Management.

Correa, T., Hinsley, A. W. and de Zuniga, H. G. (2010). Who Interacts on the Web?: The İntersection of Users' Personality and Social Media Use. Computers in Human Behavior, 26(2), 247-253.

Costa, P. T. and McCrae, R. R. (1992). Four Ways Five Factors Are Basic. Personality and Individual Differences, 13(6), 653-665.

Costa, P. T. and McCrae, R. R. (1995). Domains and Facets: Hierarchical Personality Assessment Using the Revised NEO Personality Inventory. Journal of Personality Assessment, 64(1), 21-50.

Çubukçu, Z. ve Girmen, P. (2007). Öğretmen Adaylarının Öz Yeterlik Algılarının Belirlenmesi. Eskişehir Osmangazi Üniversitesi Sosyal Bilimler Dergisi, 8(1), 57-74.

Davis, R. and Proctor, C. (2017). Fake news, Real Consequences: Recruiting Neural Networks for the Fight Against Fake News, 1-8.

De Regt, A., Montecchi, M. and Ferguson, S. L. (2019). A False Image of Health: How Fake News and Pseudo-Facts Spread in the Health and Beauty Industry. Journal of Product and Brand Management.

DeLongis, A. and Holtzman, S. (2005). Coping in Context: The Role of Stress, Social Support, and Personality in Coping. Journal of Personality, 73(6), 1633-1656.

Döş, B. ve Özşahin, C. (2019). Öğretmenlerin Sosyal Medya Bağımlılı̆̆1, Öğretmenlerin Öz-Yeterlilikleri ve Motivasyonları Arasındaki İlişkinin İncelenmesi. Elektronik Sosyal Bilimler Dergisi, 18(71), 1397-1408.

Flostrand, A., Pitt, L. and Kietzmann, J. (2019).Fake News and Brand Management: A Delphi Study of Impact, Vulnerability and Mitigation. Journal of Product and Brand Management.

George, D. and Mallery, P. (2010). Spss for Windows Step By Step. A Simple Study Guide and Reference (10. Bask1). GEN, Boston, MA: Pearson Education, Inc.

Goldberg, L. R. (1990). An Alternative "Description of Personality": The Big-Five Factor Structure. Journal of Personality and Social Psychology, 59, 1216-1229.

Gürbüz, S. ve Şahin, F. (2014). Sosyal Bilimlerde Araştırma Yöntemleri, Ankara: Seçkin Yayıncılık.

Hannah, D.R., McCarthy, I.P. and Kietzmann, J. (2015), We're Leaking, and Everything's Fine: How and Why Companies Deliberately Leak Secrets, Business Horizons, 58(6), 659667.

Horne, B.D. and Adali, S. (2017), This Just in: Fake News Packs a Lot in Title, Uses Simpler, Repetitive Content in Text Body, More Similar to Satire Than Real News, International AAAI Conference on Web and Social Media.

Hughes, D.J., Rowe,M., Batey, M. and Lee, A. (2012). A Tale of Two Sites: Twitter vs. Facebook and the Personality Predictors of Social Media Usage. Computers in Human Behavior, 28, 561-569.

Işık, M. ve Kaptangil, İ. (2018). Akıllı Telefon Bağımlılığının Sosyal Medya Kullanımı ve Beş Faktör Kişilik Özelliği ile İlişkisi: Üniversite Öğrencileri Üzerinden Bir Araştırma. Itobiad: Journal of the Human and Social Science Researches, 7(2). 
Jang, S. M. and Kim, J. K. (2018). Third Person Effects of Fake News: Fake News Regulation and Media Literacy Interventions. Computers in Human Behavior, 80, 295-302.

Kiraz, E. (2020). Sosyal Medyada Sahte Haberin Yayılmasında Kullanıcı Faktörü. INIF E-Dergi, 5(1), 9-24.

Koohikamali, M. and Sidorova, A. (2017). Information ReSharing on Social Network Sites in the Age of Fake News. Informing Science, 20.

Kumar, S. and Shah, N. (2018). False Information on Web And Social Media: A Survey. Social Media Analytics: Advances and Applications.

Kuzgun, Y. (2011). Mesleki Rehberlik ve Kariyer Danışmanlığına Giriş. Ankara: Nobel Yayıncılık.

Marchi, R. (2012). With Facebook, bLOGs, and Fake News, Teens Reject Journalistic “Objectivity". Journal of Communication Inquiry, 36(3), 246-262.

McCrae, R. R. and Costa, P. T (1990). Personality in Adulthood (First edition). New York: Guilford Press.

McCrae, R. R. and Costa, P. T. (2008). The Five-Factor Theory of Personality. In O. P. John, R. W. Robins, \& L. A. Pervin (Eds.), Handbook of personality: Theory and research (3rd ed., pp. 182-207). New York: Guilford Press.

McCrae, R. R. and John, O. P. (1992). An Introduction to the Five-Factor Model and Its Applications. Journal of Personality, 60(2), 175-215.

Mills, A. J. and Robson, K. (2019). Brand Management in the Era of Fake News: Narrative Response as A Strategy to Insulate Brand Value. Journal of Product and Brand Management.

Moore, K. and McElroy, J. C. (2012). The İnfluence of Personality on Facebook Usage Wall Postings, and Regret. Computers in Human Behavior, 28(1), 267-274.

Nelson, J. L. and Taneja, H. (2018). The Small, Disloyal Fake News Audience: The Role of Audience Availability in Fake News Consumption. New Media and Society, 20(10), 37203737.

Nyilasy, G. (2019). Fake News: When The Dark Side of Persuasion Takes Over. International Journal of Advertising, 38(2), 336-342.

Özdamar, K. (2004). Tabloların oluşturulmast, güvenirlik ve soru analizi. Paket Programlarla İstatistiksel Veri Analizi-1. 5. Bask1, Eskişehir: Kaan Kitabevi.

Özgüven, N. ve Mucan, B. (2012). The Relationship Between Personality Traits and Social Media Use. Social Behavior and Personality, 41(3), 517-528.

Özkaya, S. (2018). Sosyal Medyayı Çok Kullanan Gençlerde Narsist Kişilik Yapılanması, (Yüksek Lisans Tezi, Maltepe Üniversitesi, Sosyal Bilimler Enstitüsü).

Peterson, M. (2019). A High-Speed World With Fake News: Brand Managers Take Warning. Journal of Product and Brand Management.

Piedmont, R. L., McCrae, R. R. and Costa, P. T. (1991). Adjective Check List Scales and the Five-Factor Model. Journal of Personality and Social Psychology, 60(4), 630.

Rampersad, G. and Althiyabi, T. (2020). Fake News: Acceptance by Demographics and Culture on Social Media. Journal of Information Technology and Politics, 17(1), 1-11

Ren, J., Ozturk, P. and Luo, S. (2016). Examining Customer Responses to Fake Online Reviews: The Role of Suspicion and Product Knowledge. In Workshop on E-Business, 177184.

Ribeiro, M. H., Calais, P. H., Almeida, V. A. and Meira Jr, W. (2017). Everything I Disagree With is\# FakeNews":
Correlating Political Polarization and Spread of Misinformation, In Proceedings of Data Science + Journalism, New York.

Ross, C., Orr, E. S., Sisic, M., Arseneault, J. M., Simmering, M. G. and Orr, R. R. (2009). Personality and Motivations Associated with Facebook Use. Computers in Human Behavior, 25, 578-586.

Ryan, T. and Xenos, S. (2011). Who Uses Facebook? An Investigation Into the Relationship Between the Big Five, Shyness, Narcissism, Loneliness, and Facebook Usage. Computers in Human Behavior, 27(5), 1658-1664.

Schmitt, D. P., Allik, J., McCrae, R. R. and Benet-Martínez, V. (2007). The Geographic Distribution of Big Five Personality Traits: Patterns and Profiles of Human Self-Description Across 56 Nations. Journal of Cross-Cultural Psychology, $38(2), 173-212$.

Seidman, G. (2013). Self-Presentation and Belonging on Facebook: How Personality Influences Social Media Use and Motivations. Personality and Individual Differences, 54(3), 402-407.

Soysal, A. ve Aldal, H. (2020). Eğitsel Sosyal Ağ Kullanımında Öz-Yeterlik: Üniversite Öğrencileri Üzerine Bir Çalışma. Kahramanmaraş Sütçü İmam Üniversitesi İktisadi ve İdari Bilimler Fakültesi Dergisi, 10(1), 125-135.

Stadjkovic, A. D. and Luthans, F. (1998). Social Cognitive Theory and Self-Efficacy: Going Beyond Traditional Motivational and Behavioral Approachers. Organizational Dynamics, 26(4), 62-75.

Talwar, S., Dhir, A., Kaur, P., Zafar, N. and Alrasheedy, M. (2019). Why Do People Share Fake News? Associations Between the Dark Side of Social Media Use and Fake News Sharing Behavior. Journal of Retailing and Consumer Services, 51, 72-82.

Tandoc Jr, E. C., Lim, Z. W. and Ling, R. (2018). Defining "Fake News": A Typology of Scholarly Definitions. Digital Journalism, 6(2), 137-153.

Visentin, M., Pizzi, G. and Pichierri, M. (2019). Fake News, Real Problems for Brands: The Impact of Content Truthfulness and Source Credibility on Consumers' Behavioral Intentions Toward the Advertised Brands. Journal of Interactive Marketing, 45, 99-112.

Vosoughi, S., Roy, D. and Aral, S. (2018). The Spread of True and False News Online. Science, 359(6380), 1146-1151.

Wei, R., Lo, V. and Lu, H. (2010). The Third-Person Effect of Tainted Food Product Recall News: Examining the Role of Credibility, Attention, and Elaboration for College Students in Taiwan. Journalism and Mass Communication Quarterly, 87, 598-614.

Wisker, Z. L. (2020). The Effect of Fake News in Marketing Halal Food: A Moderating Role of Religiosity. Journal of Islamic Marketing.

Yazıcıŏlu, Y. ve Erdoğan, S. (2004). Spss Uygulamalı Bilimsel Araştırma Yöntemleri. Detay Yayıncılık, Ankara.

Zellars, K. L., Perrewe, P. L. ve Hochwarter, W. A. (2000). Burnout in Health Care: The Role of the Five Factors of Personality. Journal of Applied Social Psychology, 30(8), 1570-1598.

Zhang, D., Zhou, L., Kehoe, J. L. and Kilic, I. Y. (2016). What Online Reviewer Behaviors Really Matter? Effects of Verbal and Nonverbal Behaviors on Detection of Fake Online Reviews. Journal of Management Information Systems, 33(2), 456-481. 
Zubiaga, A., Aker, A., Bontcheva, K., Liakata, M. and Procter,

R. (2018). Detection and Resolution of Rumours in Social

Media: A Survey. ACM Computing Surveys (CSUR), 51(2),

$1-36$.

https://dictionary.cambridge.org/, Erşim Tarihi: 12.02.2021. 